\title{
Residual straw and soybean yield in succession to oat, wheat and triticale grown in crop-livestock integration system
}

\section{Palhada residual e produtividade da soja em sucessão à aveia, ao trigo e ao triticale cultivados em sistema de integração lavoura-pecuária}

\author{
Loreno Egidio TAFFAREL 1;2; Paulo Sérgio Rabello de OLIVEIRA3 ; Jeferson Tiago PIANO²; \\ Poliana Ferreira da COSTA ${ }^{4}$; Deise Dalazen CASTAGNARA ${ }^{5}$; Marcela Abbado NERES ${ }^{6}$
}

\footnotetext{
1 Parte da tese do primeiro autor

2 Doutorandos em Agronomia da Universidade Estadual do Oeste do Paraná - Campus de Marechal Cândido Rondon PR. E-mail: Ioreno.taffarel@gmail.com; jefersontpiano@hotmail.com

${ }^{3}$ Autor para correspondência, Engenheiro Agrônomo, Professor Doutor em Agronomia, Bolsista Produtividade CNPq, Centro de Ciências Agrárias da UNIOESTE - Campus de Marechal Cândido Rondon - PR, Rua Pernambuco, 1777, CEP:85.960-000 -. E-mail: rabello.oliveira@hotmail.com

${ }^{4}$ Doutoranda em Ciência e Tecnologia Ambiental, Universidade Federal da Grande Dourados - UFGD, Dourados - MS. E-mail: poliferreiradacosta@hotmail.com

${ }^{5}$ Doutora em Agronomia, Professora do Curso de Medicina Veterinária e Agronomia - Universidade Federal do Pampa Uruguaiana - RS. E-mail: deisecastagnara@yahoo.com.br

${ }^{6}$ Doutora em Zootecnia, Centro de Ciências Agrárias da UNIOESTE - Campus de Marechal Cândido Rondon - PR. E-mail: mabbadoneres@yahoo.com.br
}

Recebido em: 09-12-2014; Aceito em: 13-08-2015

\begin{abstract}
The use of oat, wheat, and triticale in crop-livestock integration system presupposes adequate grazing to permit the recovery of biomass for the direct seeding, without interfering with the productivity of soybean crop in succession. The objective of this study was to investigate the residual straw of oat IPR 126, wheat BRS Tarumã and triticale IPR 111, submitted or not to one and two grazings and the effects on the agronomic characteristics and grain yield of soybean in the growing seasons 2012/2013 and 2013/2014. The experiment was conduced using an experimental design with randomized block in a split block scheme, and four replications. In the treatment with a grazing with $0.15 \mathrm{~m}$ residue height, crops provide adequate production of biomass for direct seeding, with no difference in the residual straw in years with adequate rainfall, notwithstanding, in years with water deficit, oat culture produces higher residual straw. The previous winter crops and their managements do not interfere with plant population, thousand-grain weight and grain yield of the soybean.
\end{abstract}

Additional keywords: Glycine max, grazing, no-till system, Triticosecale, Triticum aestivum

\section{Resumo}

A utilização de aveia, de trigo e de triticale em sistema de integração lavoura-pecuária pressupõe o pastejo em níveis adequados que permitam a recomposição da biomassa para a semeadura direta, sem interferir na produtividade da cultura da soja em sucessão. O objetivo deste trabalho foi investigar a palhada residual das culturas da aveia cv. IPR 126, trigo cv. BRS Tarumã e triticale cv. IPR 111 submetidos ou não a um e dois pastejos, e os efeitos nas características agronômicas e na produtividade da soja nas safras de 2012/2013 e 2013/2014. O experimento foi conduzido em delineamento experimental em blocos ao acaso, em esquema de faixas, com quatro repetições. No tratamento com um pastejo com altura de resíduo de $0,15 \mathrm{~m}$, as culturas proporcionam produção de biomassa adequada para a semeadura direta, não havendo diferença na palhada residual, em ano com precipitação adequada; porém, em ano com déficit hídrico, a cultura da aveia produz maior palhada residual. As culturas de inverno antecessoras e os respectivos manejos não interferem na população de plantas, na massa de mil grãos e na produtividade da soja.

Palavras-chave adicionais: Glycine max, pastejo, plantio direto, Triticosecale, Triticum aestivum.

\section{Introduction}

Brazil is the world's largest soybean exporter and the second largest producer (SEAB 2013), with estimated production of 100 million tons for 2016 (CONAB, 2015). China is the largest importer of Brazilian soybeans (76\%) and the exports of soy from the state of Paraná to that country exceeds $80 \%$ of the production (SEAB, 2013). The crop yield in Paraná in 2014 was $2950 \mathrm{~kg} \mathrm{ha}^{-1}$ against $2894 \mathrm{~kg} \mathrm{ha}^{-1}$ of the national average, and in this state the soybean occupies an area larger than 9.5 million hectares (CONAB, 2015).

In west Paraná, much of the soybean 
production is sown in succession to winter maize or to winter crops. These winter crops are part of the strategy for rotation and provide soil protection and input of dry matter (DM) for their coverage. The roots result in different forms of land use, and may interfere with the physical characteristics of the soil and provide enhanced water and nutrient retention capacity, which influences the reduction of unfavorable climatic effects on succession crops (Kubo et al., 2007).

Another advantage of winter crops is their cultivation for hay or silage, and, especially, for grazing with cattle on crop-livestock integration (CLI) system and subsequent direct seeding (DS) in the remaining straw. One of the fears provided by the CLI system is the soil compaction caused by the trampling of grazing animals, which would negatively alter the density and porosity of the soil (Lopes et al., 2009).

Overgrazing caused by inadequate management of winter pastures results in low leaf area index of the pasture and lower biomass production, both of shoots and roots, and this may limit the absorption of nutrients, the water infiltration, the gas exchange and the development of roots. This has effects on the shoots, on the productivity of pasture, straw and grains of the succession crop, due to increasing soil penetration resistance and decreasing growth of soybean roots and from this condition results the paradigm of the impact of grazing on the yield of succession crops (Lunardi et al., 2008).

Excessive defoliation caused by overgrazing also results in degradation of the pasture by overuse of the areas without replacement of nutrients and bare soil causing problems of soil erosion and compaction (Balbinot Junior et al., 2009). This condition hinders or prevents regrowth and consequently the formation of straw for DS.

The addition of straws to the ground in areas under CLI system in DS is extremely important for the maintenance and increased levels of soil organic matter (SOM), which plays a key role in maintaining the production sustainable over time (Lopes et al., 2009).

On the other hand, several studies have shown that beef cattle and milk production is feasible from the point of view of optimizing the land use, provided that the use of pastures occurs appropriately and considering as a whole the CLI system (Moraes et al., 2014). It means that a systemic analysis is necessary and, under certain circumstances, to give up maximizing agricultural or livestock yields to maintain balance and optimal conditions for the production system to be efficient and sustainable in the long run (Salton et al., 2014). The result is the economic and financial maximizing of the property and per unit area, added to environmental and soil gains.

The winter crops, in a CLI system perspective, should be managed in the pasture phase to also meet the requirements of the DS and of the succession soybean crop, so that all involved production systems are paid (Silva et al., 2012).
There is also the need to validate the CLI system in the DS system, especially in emergent properties seeking new production processes that increase the profitability and sustainability of production systems with the rational cattle use (Moraes et al., 2013; Silva et al., 2014).

The aim of this study was to evaluate the residual straw from oat (IPR 126), wheat (BRS Tarumã) and triticale (IPR 111) - non-grazed or subjected to one or two grazings until the residual height of $0.15 \mathrm{~m}$-, and its effect on the components of production and productivity of soybean in succession.

\section{Material and methods}

The study was conducted in the period from 04/24/2012 to 03/21/2014, in the Experimental Farm "Professor Antônio Carlos dos Santos Pessoa" (24ํㅜㄴ 31' 56.1"' S; 54 $01^{\circ}$ ' 11.5" $\mathrm{W}$; approximate altitude of $400 \mathrm{~m}$ ), part of the State University of West Paraná Campus Marechal Cândido Rondon.

The climate of the region, according to Köppen classification, is Cfa subtropical humid mesothermal of dry winter, with well distributed rains throughout the year and hot summers. The average temperatures of the coldest quarter ranging between 17 and $18^{\circ} \mathrm{C}$, of the hottest quarter between 28 and $29^{\circ} \mathrm{C}$ and the annual between 22 and $23^{\circ} \mathrm{C}$. The normal average annual rainfall totals for the region ranging from 1600 to $1800 \mathrm{~mm}$, with the most humid quarter presenting totals ranging from 400 to $500 \mathrm{~mm}$ (Caviglione et al., 2000).

Climatic data related to the experimental period (April 2012 to March 2014) were obtained from the automatic meteorological station belonging to Unioeste/Marechal Cândido Rondon and distant about $50 \mathrm{~m}$ of the experimental area (Figure 1).

The experimental design was randomized blocks in a split block scheme, with four replications. The treatments were constituted by three winter cereal crops (oat IPR 126 - Avena sativa, triticale IPR 111 - $X$ Triticosecale Wittmack and wheat BRS Tarumã - Triticum sativum L.) in the A bands (10 $\mathrm{x}$ $18 \mathrm{~m}$ ) and the managements (no grazing (NG), one grazing (1G) and two grazings $(2 \mathrm{G})$ ) in $B$ bands $(5 x$ $30 \mathrm{~m})$ cross the $A$ bands. The plots were formed by the combination of the $A$ and $B$ bands $(5 \times 10 \mathrm{~m})$.

The experimental area was being managed under direct seeding and with soybean crops in the summer and winter maize for silage in the winter during the years 2010 and 2011. Due to its physical and chemical characteristics (Table 1), where the base saturation (V\%) presented values below 50\%, it was performed liming with dolomitic lime, with the aim of raising the base saturation to $70 \%$. Applications were without incorporation and held in April and November 2012, before the sowing of winter crops and soybeans, respectively. 


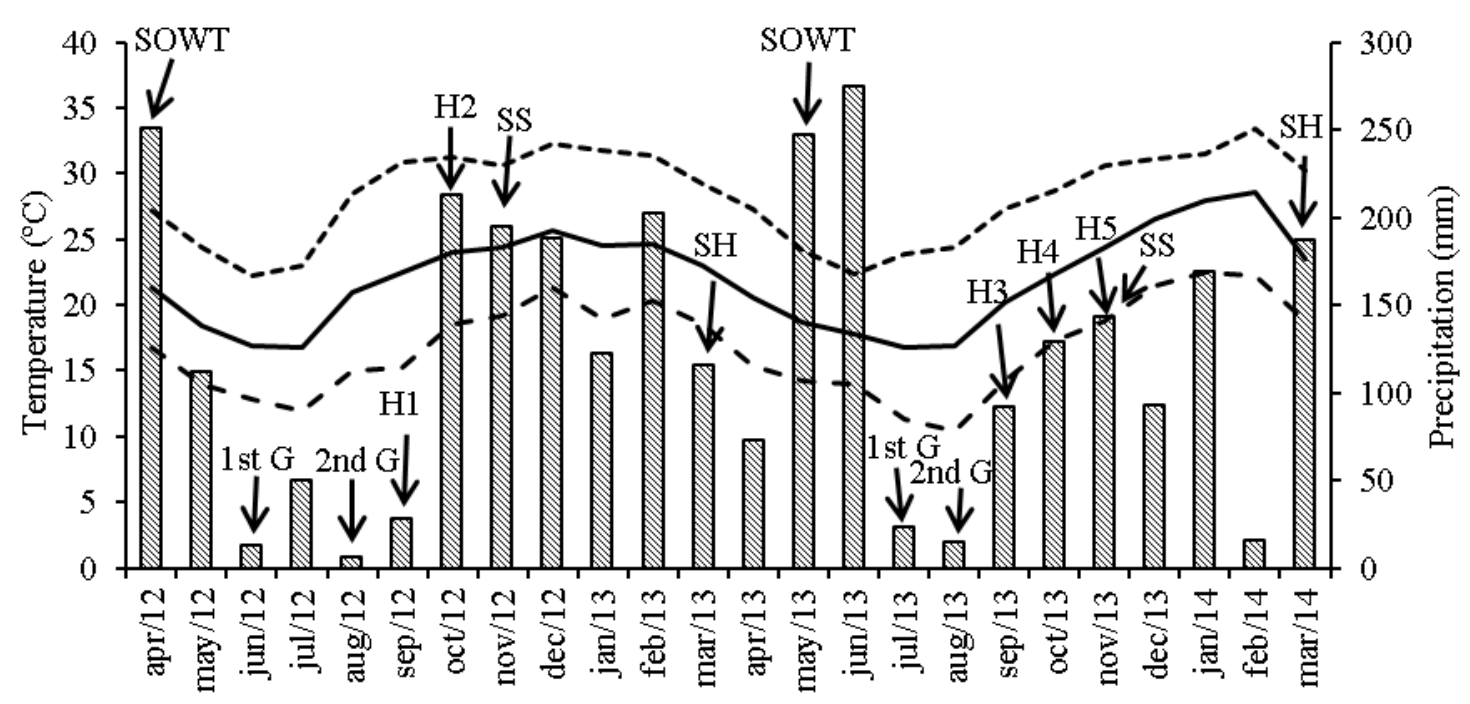

Months and Years

Cumulative rainfall (mm) - Avg. Temp. - - --Max.Temp. - - - Min. Temp.

Figure 1 - Average, maximum and minimum temperatures and precipitation $(\mathrm{mm})$ during the period of April 2012 - March 2014. SOWT: sowing of oat, wheat and triticale; $1^{\text {st }}$ G: first grazing; $2^{\text {nd }} \mathrm{G}$ : second grazing; H1: harvest of triticale - ungrazed, with one and with two grazings; $\mathrm{H} 2$ : harvest of oat and wheat - ungrazed, with one and with two grazings; $\mathrm{H} 3$ : harvest of ungrazed triticale; $\mathrm{H} 4$ : harvest of triticale with one and two grazings and harvest of wheat - ungrazed and with one grazing; H5: harvest of oat - ungrazed, with one and with two grazings and harvest of wheat with two grazings; SS: soybean sowing; SH: soybean harvest.

Table 1 - Chemical and textural characteristics of the soil, in the layer $0-30 \mathrm{~cm}$ deep, prior to implantation of winter crops.

\begin{tabular}{|c|c|c|c|c|c|c|c|c|c|c|c|c|c|c|}
\hline Depth & $P$ & OM & $\begin{array}{c}\mathrm{pH} \\
\left(\mathrm{CaCl}_{2}\right)\end{array}$ & $\mathrm{H}+\mathrm{Al}$ & $\mathrm{Al}^{3+}$ & $\mathrm{K}^{+}$ & $\mathrm{Ca}^{2+}$ & $\mathrm{Mg}^{2+}$ & BS & CEC & \multirow{2}{*}{$\begin{array}{l}\mathrm{V} \\
(\%)\end{array}$} & Clay & Silt & Sand \\
\hline$(\mathrm{cm})$ & \multicolumn{3}{|c|}{$\left(\mathrm{mg} \mathrm{dm}^{-3}\left(\mathrm{~g} \mathrm{dm}^{-3}\right)\right.$} & \multicolumn{7}{|c|}{ 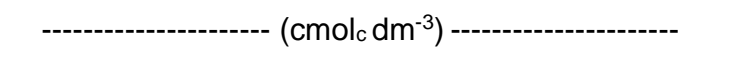 } & & \multicolumn{3}{|c|}{------- $\left(\mathrm{g} \mathrm{kg}^{-1}\right)$------ } \\
\hline $0-10$ & 24 & 33 & 4.55 & 9.40 & 0.46 & 0.53 & 4.56 & 1.54 & 6.63 & 16.02 & 42 & 681 & & 53 \\
\hline $10-20$ & 25 & 33 & 4.65 & 8.62 & 0.34 & 0.44 & 5.32 & 1.67 & 7.42 & 16.04 & 46 & 752 & & 49 \\
\hline 0-30 & 12 & 32 & 4.77 & 7.47 & 0.19 & 0.25 & 5.49 & 1.75 & 7.49 & 14.95 & 50 & 707 & 239 & 55 \\
\hline
\end{tabular}

$\mathrm{P}$ and $\mathrm{K}-$ Extractor MEHLICH-1; $\mathrm{Al}, \mathrm{Ca}$ and $\mathrm{Mg}=\mathrm{KCl} 1 \mathrm{~mol} \mathrm{~L}^{-1} ; \mathrm{H}+\mathrm{Al}=\mathrm{pH} \mathrm{SMP}$ (7.5).

The sowing of winter crops was held on 04-24-2012 and 05-10-2013. In both agricultural years were used $60 \mathrm{~kg} \mathrm{ha}^{-1}$ oat and $90 \mathrm{~kg} \mathrm{ha}^{-1}$ wheat. For triticale were used $40 \mathrm{~kg} \mathrm{ha}^{-1}$ in 2012 and $60 \mathrm{~kg} \mathrm{ha}^{-1}$ in 2013. The spacing between the lines was $0.17 \mathrm{~m}$, by using the DS system with double disc-type trencher system. It was used $100 \mathrm{~kg} \mathrm{ha}^{-1}$ of the formulate NPK 8-20-20 as fertilizer at sowing and $120 \mathrm{~kg} \mathrm{ha}^{-1} \mathrm{~N}$ in the form of urea, for top dressing, which was performed in two stages $\left(60 \mathrm{~kg} \mathrm{ha}^{-1}\right.$ per application) in the plots without grazing and with one grazing, and three times ( $40 \mathrm{~kg} \mathrm{ha}^{-1}$ per application) in the plots with two grazings. The coverage fertilizations in 2012 were held in 05-24, 07-08 and 08-15 and in 2013 in 06-08, 07-20 and 08-24, respectively, ie, the first one was after the crop's tillering and the others after grazing.
In 2012, the first grazing was performed at 63 days after sowing (26th to 29th of June 2012) and in 2013 at 59 days after sowing ( $8^{\text {th }}$ to $10^{\text {th }}$ of July 2013 ), when the plants had $30 \mathrm{~cm}$ in height or at least one $\mathrm{kg}$ of green mass $\mathrm{m}^{-2}$. The average canopy height was measured at three points of each plot with the help of ruler graduated in centimeters and the collection of the material to assess the amount of green mass was performed with a metal frame with an area of $0.25 \mathrm{~m}^{2}$, repeated twice in each experimental unit. The second grazing was conducted with a 37 days interval regarding the first grazing, both in 2012 and in 2013 ( $2^{\text {nd }}$ to $4^{\text {th }}$ of August 2012 and $14^{\text {th }}$ to $15^{\text {th }}$ of August 2013). The animals remained in the area until the residual height of $0.15 \mathrm{~m}$ of the plants. For the grazing, it was used ten Holstein cows with an average weight of $663 \mathrm{~kg}$ and 
average individual production of daily $25 \mathrm{~L}$.

The harvests of winter crops were held on the following dates: In 2012: a) 09-15-2012 - triticale managements NG, $1 G$ and 2G; b) 10-18-2012 - oat management $N G$ and wheat managements $N G$ and $1 G$; c) $10-25-2012$ - oat management $1 G$ and wheat management $2 \mathrm{G}$ and 10-31-2012 - oat management 2G. In 2013: a) 09-26-2013 - triticale management NG; b) 10-07-2013 - triticale management $1 \mathrm{G}$, wheat managements $N G$ and $1 G$; c) 10-23-2013 triticale management 2G; d) 11-01-2013 - oat management NG; e) 11-07-2013 - oat managements $1 G$ and $2 G$ and 11-11-2013 - wheat management $2 G$.

After the end of the winter crops cycle, with the respective harvest of grains of each species and in each type of management (NG, $1 \mathrm{G}$ and $2 \mathrm{G}$ ), the soybean sowings have been held on 11-22-2012 (BMX Potência RR) and 11-25-2013 (SYN 1059 RR).

The area has been previously desiccated using glyphosate (isopropylamine salt) at a dose of $1440 \mathrm{~g}$ ai ha-1, with a syrup volume of $250 \mathrm{~L} \mathrm{ha}^{-1}$. For fertilization at sowing were applied $347 \mathrm{~kg} \mathrm{ha}^{-1}$ of a commercial formulate 2-20-20 (N- $\left.\mathrm{P}_{2} \mathrm{O}_{5}-\mathrm{K}_{2} \mathrm{O}\right)$, being held based on chemical analysis of soil (Sfredo, 2008). The seeds were treated with fungicides carbendazim $\left(150 \mathrm{~g} \mathrm{~L}^{-1}\right)+\operatorname{tiran}\left(350 \mathrm{~g} \mathrm{~L}^{-1}\right)$ $2 \mathrm{~mL} \mathrm{~kg}^{-1}$ seed, insecticide fipronil (250 $\left.\mathrm{g} \mathrm{L}^{-1}\right)$ $0.8 \mathrm{~mL} \mathrm{~kg}^{-1}$ seed and inoculated in order to achieve a million Bradyrhizobium japonicum cells per seed.

The spacings, as well as the density of seeding, were performed in accordance with the recommendation for each cultivar, being the quantity of seed per linear meter of 15 for the cultivar BMX Potência RR and of 16 for the cultivar SYN 1059 $\mathrm{RR}$, and in both years the row spacing was $0.45 \mathrm{~m}$. For seeding, it was used a seeder fertilizer with double disc coupled to a tractor, the seeds being deposited to an average depth of $0.04 \mathrm{~m}$. During the crop development cycle, fungicide applications were made: triazole at a dose of $130 \mathrm{~g}_{\text {ai ha- }}{ }^{-1}$, strobilurin + triazole at a dose of $60 \mathrm{~g}$ and $24 \mathrm{~g}$ ai ha-1, respectively; and also insecticide applications: neonicotinoid at a dose of $100 \mathrm{~g}$ ai ha- $\mathrm{ha}^{-1}+$ pyrethroid and benzoylurea at doses of $26 \mathrm{~g}+26 \mathrm{~g}$ ai ha-1, respectively, with a syrup volume of $250 \mathrm{~L} \mathrm{ha}^{-1}$. The soybean harvest was held on 03-12-2013 and 03-21-2014, in the useful area $\left(36 \mathrm{~m}^{2}\right)$ of each plot, manually, with subsequent mechanical track.

It was evaluated the DM of residual straw after each grazing in the years 2012 and 2013 and the DM of residual straw after harvest of winter crops in 2012, considering the average of two samples of $0.25 \mathrm{~m}^{2}$ in each plot and four replicates per treatment. The samples were subjected to drying $\left(55^{\circ} \mathrm{C}\right.$ for 72 hours) and the results were converted to one hectare. In each plot were obtained the average height of ten plants with the use of ruler Table 2 - Dry matter of residual straw of oat IPR 126, wheat BRF Tarumã and triticale IPR 111, after non- graduated in centimeters; number of pods per plant, number of seeds per pod and stem diameter, determined using a digital caliper. The thousand grain weight was obtained under the Rules for Seed Analysis (Brasil, 2009). The population of plants and grain yield expressed in $\mathrm{kg} \mathrm{ha}^{-1}$ were obtained from the amount of plants and production of two central lines of the plot, in an area of $2.25 \mathrm{~m}^{2}$.

The data were submitted to analysis of variance by $\mathrm{F}$ test and the averages compared by Tukey test at $5 \%$ probability.

\section{Results and discussions}

In August 2012, the average dry matter of residual straw after grazing for crops of oat, wheat and triticale was 2701, 1342 and $2493 \mathrm{~kg} \mathrm{ha}^{-1}$, respectively. For the $1 \mathrm{G}, 2 \mathrm{G}$ and $\mathrm{NG}$ managements, it was 1831,1100 and $3606 \mathrm{~kg} \mathrm{ha}^{-1}$, respectively. There was interaction between cultures and managements, whose deployment resulted in higher average residual straw in the NG plots for crops of oat and triticale than in the $1 G$ and $2 G$ managements (Table 2). For wheat, there were no significant differences for the residual straw after the $N G, 1 G$ and $2 G$ managements, which can be attributed to the long cycle of the cultivar BRS Tarumã and its high capacity for regrowth and tillering.

After the second grazing, crops of oat, wheat and triticale completed their cycle with the production of grains, respectively for the NG, $1 G$ and $2 \mathrm{G}$ managements. The amount of straw after harvest of grain was measured only in 2012 (Table 2). The culture of oat provided higher amount of dry matter of straw, averaging $8194 \mathrm{~kg} \mathrm{ha}^{-1}$, followed by wheat (4809 kg ha-1) and triticale $\left(2125 \mathrm{ha}^{-1}\right)$. The reason was the longest cycles of oat IPR 126 and wheat BRS Tarumã, associated with an increased height and average population of plants before the harvest of oat $\left(95.7 \mathrm{~cm} ; 265.0\right.$ plants $\left.\mathrm{m}^{-2}\right)$, relative to wheat $\left(40.6 \mathrm{~cm} ; 436.5\right.$ plants $\left.\mathrm{m}^{-2}\right)$ and triticale $(71.3 \mathrm{~cm}$; 85.3 plants $\mathrm{m}^{-2}$ ).

The NG management resulted in higher dry matter residual straw $\left(6368 \mathrm{~kg} \mathrm{ha}^{-1}\right)$, however, it did not differ from the management with $1 \mathrm{G}$ $\left(4796 \mathrm{~kg} \mathrm{ha}^{-1}\right)$, and the least amount of residual straw occurred in the plots managed with $2 \mathrm{G}$ (3964 kg ha-1). The occurrence of $50.8 \mathrm{~mm}$ (Figure 1) of rain in July after the first grazing (held from 26th to 29th of June 2012) contributed to this result, against $6.6 \mathrm{~mm}$ of rain in August after the second grazing (2nd to 4th of August), enabling better utilization efficiency of nitrogen applied in coverage after the first grazing, since this nutrient is the main enabler of growth of grasses (Zamarchi et al., 2014). 
-grazed management and managements with one and two grazings in the years 2012 and 2013.

\begin{tabular}{|c|c|c|c|c|}
\hline \multirow{3}{*}{ Crop } & \multicolumn{3}{|c|}{ (1)Management } & \multirow{3}{*}{ Average } \\
\hline & $1 \mathrm{G}$ & $2 \mathrm{G}$ & NG & \\
\hline & \multicolumn{3}{|c|}{ Residual straw after grazing $\left(\mathrm{kg} \mathrm{ha}^{-1}\right)-$ August 2012} & \\
\hline Oat & $1990 \mathrm{Ab}$ & $1675 \mathrm{Ab}$ & $4440 \mathrm{Aa}$ & 2701 \\
\hline Wheat & $1540 \mathrm{Aa}$ & $650 \mathrm{Aa}$ & $1840 \mathrm{Ba}$ & 1343 \\
\hline Triticale & $1965 \mathrm{Ab}$ & $975 \mathrm{Ab}$ & $4540 \mathrm{Aa}$ & 2493 \\
\hline Average & 1831 & 1100 & 3606 & \\
\hline CV (\%) $1 ; 2 ; 3$ & 47.60 & 31.54 & 29.31 & \\
\hline \multicolumn{5}{|c|}{ Straw after grain harvest $\left(\mathrm{kg} \mathrm{ha}^{-1}\right)$ - Year 2012} \\
\hline Oat & 7758 & 5401 & 11424 & $8194 \mathrm{~A}$ \\
\hline Wheat & 4692 & 4782 & 4952 & $4809 \mathrm{~B}$ \\
\hline Triticale & 1937 & 1708 & 2728 & $2125 \mathrm{C}$ \\
\hline Average & $4796 a b$ & $3964 \mathrm{~b}$ & $6368 \mathrm{a}$ & \\
\hline CV (\%) 1;2; 3 & 36.35 & 33.79 & 44.83 & \\
\hline \multicolumn{5}{|c|}{ Residual straw after grazing $\left(\mathrm{kg} \mathrm{ha}^{-1}\right)-$ August 2013} \\
\hline Oat & $3950 \mathrm{Aa}$ & $1600 \mathrm{Ab}$ & $3630 \mathrm{Aa}$ & 3060 \\
\hline Wheat & $4470 \mathrm{Aa}$ & $1310 \mathrm{Ac}$ & $2980 \mathrm{Ab}$ & 2919 \\
\hline Triticale & $3670 \mathrm{Aa}$ & $2480 \mathrm{Ab}$ & $2980 \mathrm{Aab}$ & 3036 \\
\hline Average & 4029 & 1796 & 3189 & \\
\hline CV (\%) $1 ; 2 ; 3$ & 35.13 & 23.21 & 20.79 & \\
\hline
\end{tabular}

(1) Means followed by the same capital letter in the column and lower case in the line, do not differ statistically by the Tukey test (5\%); 1G: one grazing; 2G: 2 grazing; NG: no grazing; CV: coefficient of variation 1, 2 and 3 (\%).

For the direct seed (DS) system to be conducted properly, it is necessary to adopt crop rotation schemes and CLI system, in order to maintain as straw on the soil between 6000 (Cruz et al., 2010) and $8000 \mathrm{~kg} \mathrm{ha}^{-1} \mathrm{DM}$ per year (Lopes et al., 2009). This means that for CLI systems in which are carried out one or even two cycles of summer crops (corn and soybean) and one of winter crops (oat, wheat, triticale), totaling two to three cycles of annual crops in the same area, each culture must be managed so as to leave at least three to two tons of DM over the ground, respectively (Lopes et al., 2009, Cruz et al., 2010; Santos et al., 2013; Silva et al., 2014).

For oat and wheat occurred an increase in the amount of mass of $203.32 \%$ and $258.05 \%$, respectively, produced after grazing until harvest. This can be explained by the low amount of rainfall between June and September/2012 and the high rainfall (>150 mm monthly) from October/2012 (Figure 1), associated with the crop cycle of these cultures and their recoverability. The explanation for the lesser amount of straw left by the triticale was because the harvest, for all managements, was performed on 09-15-2012, ie the cereal cycle occurred during a period of low precipitation (Figure 1). Another factor was the low average population of triticale plants (85.3 plants $\mathrm{m}^{-2}$ ), due to the extraction of plants after grazing and lower capacity of regrowth and tillering.
The recommended population of plants for triticale is between 400 and $500 \mathrm{~m}^{-2}$ (Mut et al., 2005).

The measurement of the amount of straw immediately after the second grazing in 2013 resulted in the interaction between culture and managements, with the greatest amount of residual DM of oat occurring in the NG and $1 \mathrm{G}$ managements (Table 2). The wheat with $1 \mathrm{G}$, on its turn, resulted in the largest amount of residual DM after the second grazing, followed by the NG plot and then $2 \mathrm{G}$, and the likely explanation is that the wheat with $1 \mathrm{G}$ produced a larger amount of tillers per area (230.9 tillers $\left.\mathrm{m}^{-2}\right)$ than in the 2G (204.4 tillers $\mathrm{m}^{-2}$ ) and NG (127.9 tillers $\mathrm{m}^{-2}$ ) managements. Triticale with $1 \mathrm{G}$ also resulted in higher amounts of residual $\mathrm{DM}$ in relation to the plots with $2 \mathrm{G}$, nonetheless both did not differ in relation to NG plots.

Lunardi et al. (2008) reported DM residual mass of 798,3084 and $8300 \mathrm{~kg} \mathrm{ha}^{-1}$ for the ryegrass culture non-grazed and with moderate and low intensity of grazing -, namely 2.5 and 5.0 times the consumption potential, in four grazing cycles lasting two days each. These data are similar to the present study because the plots with moderate grazing, equivalent to two grazings, resulted in fewer residual DM.

In soybeans grown in succession to cultures of oat, wheat and triticale, in both the seasons $2012 / 2013$ and $2013 / 2014$, there were no interactions between the managements and the previous crops 
(Table 3). For the managements with one grazing (1G) or two grazings (2G) and without grazing (NG) there was significance to the average results in the number of pods per plant and grains per pod for the 2012/2013 harvest. The effect of previous crops on soy resulted in differences in the average results for plant height at the 2013/2014 harvest.

The results for the height of the soybean plants in the 2012/2013 harvest were not significant and the height was $104.48 \mathrm{~cm}$ in the plots with one grazing, $104.13 \mathrm{~cm}$ in non-grazed plots and 93.75 $\mathrm{cm}$ in the plots with two grazings (Table 3 ). That is, considering the hypothesis that this has occurred because of the lower amount of DM due to grazing (Table 2) (Santos et al., 2013), or of effects on soil porosity due to the presence of animals (Flores et al., 2007; Flores \& Tracy, 2012) and the water deficit period (Lopes et al., 2009), this situation tends to gradually reduce with the use of the crop rotation system in three to four years (Calonego et al., 2010), or grazing with residual height of more than $0.10 \mathrm{~m}$ (Kunrath et al., 2015), as can be seen in the 2013/2014 harvest (Table 3).

In the 2013/2014 season, there was smaller height of the soybean SYN 1059 plants in succession to the triticale IPR 111 culture, while the greater height occurred with the wheat BRS Tarumã crop (Table 3 ). These results are similar to those reported by Brandt et al. (2006), who found no differences in the height of soybean plants when comparing succession systems in no-tillage, including oat and wheat. The lower height of the soybean in sucession to triticale in the 2013/2014 season can be attributed to the synergistic effects between the synchronization of the nitrogen mineralization-immobilization in the growth of soybean (Assmann et al., 2014) due to lower residual DM production provided by triticale (Table 2) (Santos et al., 2013). The triticale culture also resulted in increased soil penetration resistance in the layer between 0.20 and $0.30 \mathrm{~m}$ when compared to oat and wheat (Piano et al., 2015), besides the fact that the components from its roots can reduce the size of the soybean roots (Lira et al., 2010) and in this experiment in the 2012/2013 season, the soybean sowing was carried out 68 days after the harvest of triticale and so there was no influence, while in the 2012/2013 season, the sowing was held 60,49 and 33 days after the harvest of triticale for $N G, 1 G$ and $2 G$ managements.

Table 3 - Plant height, stem diameter, number of pods per plant and number of grains per pod of the soybean BMX Potência RR in the 2012/2013 harvest and SYN 1059 in the 2013/2014 harvest in succession to oat, wheat, and triticale grown in crop-livestock integration system.

\begin{tabular}{|c|c|c|c|c|c|c|c|c|}
\hline \multirow{2}{*}{$\begin{array}{l}\text { Harvest } \\
\text { Management/Cron }\end{array}$} & \multicolumn{4}{|c|}{ (1)2012/2013 } & \multicolumn{4}{|c|}{ (1)2013/2014 } \\
\hline & $1 \mathrm{G}$ & $2 \mathrm{G}$ & NG & Average & $1 \mathrm{G}$ & $2 \mathrm{G}$ & $N G$ & Average \\
\hline & \multicolumn{8}{|c|}{ Plant height $(\mathrm{cm})$} \\
\hline Oat & 105.67 & 77.46 & 103.50 & $95.54 \mathrm{~A}$ & 82.31 & 82.15 & 76.90 & $80.45 \mathrm{AB}$ \\
\hline Wheat & 107.13 & 100.14 & 104.63 & $103.97 \mathrm{~A}$ & 83.70 & 79.27 & 83.40 & $82.12 \mathrm{~A}$ \\
\hline Triticale & 99.60 & 103.67 & 105.33 & $102.87 \mathrm{~A}$ & 78.25 & 75.12 & 77.20 & $76.86 \mathrm{~B}$ \\
\hline Average & $104.13 \mathrm{a}$ & $93.75 \mathrm{a}$ & $104.48 \mathrm{a}$ & & $81.42 \mathrm{a}$ & 78.85 & $79.17 \mathrm{a}$ & \\
\hline \multirow[t]{2}{*}{ CV (\%) $1 ; 2 ; 3$} & 18.72 & 15.97 & 15.08 & & 5.15 & 5.36 & 4.01 & \\
\hline & \multicolumn{8}{|c|}{ Stem diamenter $(\mathrm{mm})$} \\
\hline Oat & 8.48 & 7.93 & 8.42 & $8.28 \mathrm{~A}$ & 7.50 & 7.99 & 7.35 & $7.61 \mathrm{~A}$ \\
\hline Wheat & 9.20 & 8.32 & 8.97 & $8.83 \mathrm{~A}$ & 8.18 & 7.87 & 8.04 & $8.03 \mathrm{~A}$ \\
\hline Triticale & 8.83 & 8.17 & 8.62 & $8.54 \mathrm{~A}$ & 8.02 & 7.96 & 7.58 & $7.85 \mathrm{~A}$ \\
\hline Average & $8.14 \mathrm{a}$ & $8.67 \mathrm{a}$ & $8.84 \mathrm{a}$ & & $7.90 \mathrm{a}$ & $7.94 \mathrm{a}$ & $7.66 \mathrm{a}$ & \\
\hline \multirow[t]{2}{*}{ CV (\%) 1;2;3 } & 14.59 & 7.86 & 6.47 & & 8.04 & 10.77 & 10.44 & \\
\hline & \multicolumn{8}{|c|}{ Number of pods per plant } \\
\hline Oat & 48.13 & 36.81 & 35.70 & $40.21 \mathrm{~A}$ & 46.63 & 50.48 & 43.15 & $46.75 \mathrm{~A}$ \\
\hline Wheat & 50.23 & 35.85 & 45.40 & $43.83 \mathrm{~A}$ & 49.57 & 44.32 & 48.50 & $47.47 \mathrm{~A}$ \\
\hline Triticale & 42.23 & 39.00 & 39.16 & $40.13 \mathrm{~A}$ & 43.00 & 47.43 & 41.37 & $43.93 \mathrm{~A}$ \\
\hline Average & $46.86 \mathrm{a}$ & $37.22 \mathrm{~b}$ & $40.09 \mathrm{~b}$ & & $46.40 \mathrm{a}$ & $47.41 \mathrm{a}$ & $44.34 \mathrm{a}$ & \\
\hline \multirow[t]{2}{*}{ CV (\%) $1 ; 2 ; 3$} & 19.03 & 9.53 & 15.23 & & 7.63 & 16.09 & 22.72 & \\
\hline & \multicolumn{8}{|c|}{ Number of grains per pod } \\
\hline Oat & 2.23 & 2.07 & 1.97 & $2.09 \mathrm{~A}$ & 1.82 & 2.06 & 1.93 & $1.94 \mathrm{~A}$ \\
\hline Wheat & 2.05 & 1.97 & 1.83 & $1.95 \mathrm{~A}$ & 2.05 & 1.80 & 2.03 & $1.96 \mathrm{~A}$ \\
\hline Triticale & 2.12 & 1.97 & 1.83 & $1.97 \mathrm{~A}$ & 2.05 & 2.01 & 1.98 & $2.01 \mathrm{~A}$ \\
\hline Average & $2.13 \mathrm{a}$ & $2.00 \mathrm{ab}$ & $1.87 \mathrm{~b}$ & & $1.97 \mathrm{a}$ & $1.96 \mathrm{a}$ & $1.98 \mathrm{a}$ & \\
\hline CV (\%) $1 ; 2 ; 3$ & 10.02 & 9.71 & 8.42 & & 7.85 & 10.96 & 8.49 & \\
\hline
\end{tabular}

(1) Means followed by the same capital letter in the column and lower case in the line, do not differ statistically by the Tukey test (5\%); 1G: one grazing; 2G: 2 grazings; NG: no grazing; CV: coefficient of variation 1, 2 and 3 (\%). In both harvests, there were no differences in stem diameter, both in relation to the culture and by 
the managements (Table 3). Even though greater or lesser amount of residual DM according to the cultures (oat, wheat and triticale) and managements (1G, 2G or NG) have resulted in different cycling of nutrients and nitrogen supply changes to the soybean (Santos et al., 2013; Santos et al., 2014), variations of this nutrient do not alter the soybean stem diameter (Bahry et al., 2013).

In the 2012/2013 season, the number of pods per plant was higher $(p<0.05)$ where only one grazing occurred and the number of grains per pod was also higher with one grazing compared to no grazing, but did not differ with the two grazings management. For these characteristics there were no differences ( $p>0.05$ ) in the $2013 / 2014$ season.

In this same experiment in 2012, Piano et al. (2015) reported that there were no differences regarding the penetration resistance to the depth of soil of $0.20 \mathrm{~m}$, but in the layer between 0.20 and $0.30 \mathrm{~m}$ there was less resistance to penetration in the plots with one grazing compared to no grazing and both did not differ with two grazings. This explains, in the 2012/2013 harvest, the higher number of pods per plant and the largest number of grains per pod with one grazing (Table 3 ), since it was observed that the plant population (PP) in the plots with one grazing
(Table 4) was $9.95 \%$ lower than the PP of the nongrazed plots. According to Vazquez et al. (2008), the smaller plant population favors soybean branching, and, consequently, the larger number of pods per plant. On the other hand, with two grazings there is the effect of the greater export of nutrients and effects involving synchronization of the release of nutrients by the previous crops (Assmann et al., 2014), being added to this the lower amount of DM left on the soil (Table 2).

Carvalho et al. (2010) reported agronomic results of soybean in succession to oat crop grazed at $0.10 ; 0.20 ; 0.30 ; 0.40 \mathrm{~m}$ and without grazing and found a smaller number of grains per plant when grazed at moderate intensity (from 0.20 to $0.30 \mathrm{~m}$ ), notwithstanding there were no differences in productivity because there was compensation for the greater number of plants per area, fact which was also observed in this study (Tables 3 and 4 ).

The managements (1G, 2G and $N G$ ) and cultures (oat IPR 126, wheat BRS Tarumã and triticale IPR 11) did not affect $(p>0.05)$ the population of plants per hectare, the thousand grain weight and the productivity of both soybean cultivars, BMX Potência RR in the 2012/2013 harvest and SYN 1059 RR in the 2013/2014 harvest (Table 4).

Table 4 - Plant population, thousand grain weight, and grain yield of the soybean BMX Potência RR in the 2012/2013 harvest and SYN 1059 RR in the 2013/2014 harvest in succession to oat, wheat, and triticale grown in crop-livestock integration system.

\begin{tabular}{|c|c|c|c|c|c|c|c|c|}
\hline \multirow{2}{*}{ Harvest } & \multicolumn{4}{|c|}{ (1)2012/2013 } & \multicolumn{4}{|c|}{ (1)2013/2014 } \\
\hline & $1 \mathrm{G}$ & $2 \mathrm{G}$ & NG & Mean & $1 \mathrm{G}$ & $2 \mathrm{G}$ & NG & Mean \\
\hline & \multicolumn{8}{|c|}{ Plant population (plants ha ${ }^{-1}$ ) } \\
\hline Oat & 229.629 & 255.555 & 262.962 & $249.382 \mathrm{~A}$ & 203.222 & 220.000 & 187.778 & $195.555 \mathrm{~A}$ \\
\hline Wheat & 229.629 & 262.962 & 244.444 & $245.679 \mathrm{~A}$ & 200.000 & 203.333 & 183.333 & $201.111 \mathrm{~A}$ \\
\hline Triticale & 248.148 & 285.185 & 270.370 & $267.901 \mathrm{~A}$ & 184.444 & 211.111 & 207.778 & $203.703 \mathrm{~A}$ \\
\hline Mean & $235.802 \mathrm{a}$ & $267.901 \mathrm{a}$ & $259.259 \mathrm{a}$ & & $195.925 \mathrm{a}$ & $211.481 \mathrm{a}$ & $192.962 \mathrm{a}$ & \\
\hline \multirow[t]{2}{*}{$\overline{C V}(\%) 1 ; 2 ; 3$} & 13.00 & 13.13 & 10.88 & & 17.64 & 17.77 & 17.64 & \\
\hline & \multicolumn{8}{|c|}{ Thousand grain weight $(\mathrm{g})$} \\
\hline Oat & 110.20 & 111.10 & 116.86 & $112.72 \mathrm{~A}$ & 89.40 & 90.00 & 92.74 & $90.71 \mathrm{~A}$ \\
\hline Wheat & 114.06 & 115.08 & 104.73 & $111.29 \mathrm{~A}$ & 93.74 & 87.90 & 91.35 & $91.00 \mathrm{~A}$ \\
\hline Triticale & 117.05 & 111.36 & 121.18 & $116.53 \mathrm{~A}$ & 88.04 & 85.77 & 93.37 & $89.06 \mathrm{~A}$ \\
\hline Mean & $113.77 \mathrm{a}$ & $112.51 \mathrm{a}$ & $114.25 \mathrm{a}$ & & $90.40 \mathrm{a}$ & $87.89 \mathrm{a}$ & $92.49 \mathrm{a}$ & \\
\hline \multirow[t]{2}{*}{$\overline{C V}(\%) 1 ; 2 ; 3$} & 11.93 & 8.48 & 6.43 & & 6.75 & 4.63 & 4.78 & \\
\hline & \multicolumn{8}{|c|}{ Grain yield $\left(\mathrm{kg} \mathrm{ha}^{-1}\right)$} \\
\hline Oat & 2.897 & 2.192 & 2.309 & $2.466 \mathrm{~A}$ & 1.333 & 1.519 & 1.295 & $1.383 \mathrm{~A}$ \\
\hline Wheat & 2.642 & 2.136 & 2.128 & $2.302 \mathrm{~A}$ & 1.500 & 1.401 & 1.281 & $1.393 \mathrm{~A}$ \\
\hline Triticale & 2.525 & 2.349 & 2.331 & $2.401 \mathrm{~A}$ & 1.396 & 1.409 & 1.294 & $1.266 \mathrm{~A}$ \\
\hline Mean & $2.688 \mathrm{a}$ & $2.225 \mathrm{a}$ & $2.256 \mathrm{a}$ & & $1.410 \mathrm{a}$ & $1.443 \mathrm{a}$ & $1.290 \mathrm{a}$ & \\
\hline CV (\%) $1 ; 2 ; 3$ & 35.56 & 18.01 & 14.96 & & 23.40 & 17.22 & 13.63 & \\
\hline
\end{tabular}

(1) Means followed by the same capital letter in the column and lower case in the line, do not differ statistically by the Tukey test (5\%); 1G: one grazing; 2G: 2 grazing; NG: no grazing; CV: coefficient of variation 1, 2 and 3 (\%).

Root exudates of winter crops of vetch, black oat, wheat and triticale interfere in the percentage of germination of soy seeds (Bortolini \& Fortes, 2005) and this may interfere with the final plant population, which did not occur in this experiment. However, in the 2012/2013 crop, the plant population of plots with
$2 \mathrm{G}$ was $3.33 \%$ and $13.57 \%$ higher than the $\mathrm{NG}$ and $1 G$ plots and, in the $2013 / 2014$ crop, plots with $2 G$ had population $9.60 \%$ and $7.94 \%$ higher than the NG and $1 G$ plots, respectively. These population variations did not affect the productivity because soy is able to compensate efficiently the available spaces 
by means of changes in its morphology and productivity components, mainly by increasing branching (Vazquez et al., 2008).

The population of soybean plants in succession to triticale, compared to oat $(7.43 \% ; 4.17 \%)$ and wheat $(9.05 \%$; $12.89 \%)$ in both $2012 / 2013$ and $2013 / 2014$ crops (Table 4), might have been due to the allelopathic effect of the root system of oat and wheat (Lira et al., 2010). The harvest of triticale in 2012 was 68 days before the soybean sowing, and, in 2013,33 days. The harvest of oat was 35 (1G), 28 (2G) and 22 (NG) days before soybean sowing in 2012, and 24 and 18 days before soybean sowing in 2013. The wheat was harvested 34 and 27 days before soybean sowing in 2012 and 48 and 14 days before soybean sowing in 2013.

In water deficit situations, the lower residual DM provided by grazing to the height of $0.10 \mathrm{~m}$ may have further reduced soil moisture at planting, which may have decreased the percentage of germination of soy seeds, fact that did not occur under managements with residual mass height of $0.20,0.30$ and $0.40 \mathrm{~m}$ (Lopes et al., 2009). Oat managements with the same residual DM $(0.10 ; 0.20 ; 0.30$ and $0.40 \mathrm{~m})$ in adequate condition of precipitation had no influence on plant population and neither on soybean yield (Flores et al., 2007). Lunardi et al. (2008) reported that there was a greater number of pods on treatment with low grazing intensity ( 5 times the potential of animal consumption) when compared with moderate grazing intensity ( 2.5 times the consumption potential) and no grazing. These authors found a lower thousand grain weight in the non-grazed area in relation to the average of the grazed areas with moderate or low grazing due to the offsetting effect, as with more pods per plant there is a reduction in the thousand grain weight and vice versa. They reported that there were no differences between the respective intensities of grazing on the thousand grain weight, a result that is similar to that found in the present study.

Soybean yield, in both seasons (2012/2013 and 2013/2014), was not influenced by the cultures and managements (Table 4). Nevertheless, it was below the expected, especially in the 2013/2014 season, due to low precipitation (Figure 1), in February $2014(16.4 \mathrm{~mm})$, when the plants were between the R5 and R7 stages, influencing the grain filling, as can be observed in the thousand grain weight. The results reinforce that soy can be grown in crop-livestock integration systems conducted in winter crops grazed in heights of $0.15 \mathrm{~m}$, without incurring losses to productivity, corroborating the results of long-term experiments conducted by Santos et al. (2013) and Kunrath et al. (2015).

\section{Conclusions}

The oat IPR 126, wheat BRS Tarumã and triticale IPR 111 crops after one grazing provide residual straw that allows its use in crop-livestock integration systems and direct seeding of soybean in succession.
In years with low rainfall in winter, regardless of the management adopted, most residual straw is brought about by the culture of oat IPR 126, followed by wheat BRS Tarumã and by the triticale IPR 111. In years with adequate rainfall, there are no differences in the amount of straw produced by the cultures.

The plant population, thousand grain weight and yield of the soybean are not changed by previous winter crops or managements with or without grazings in the crop-livestock integration.

\section{References}

Assmann TS, Bortolli MA, Assmann AL, Soares AB, Pitta CSR, Franzluebbers AJ, Glienke CL, Assmann JM (2014) Does cattle grazing of dual-purpose wheat accelerate the rate of stubble decomposition and nutrients released? Agriculture, Ecosystems and Environment, 190: 37-42. DOI: 10.1016/j.agee.2014.01.011.

Bahry CA, Venske E, Nardino M, Fin SS, Zimmer PD, Souza VQ, Caron BO (2013) Características morfológicas e componentes de rendimento da soja submetida à adubação nitrogenada. Revista Agrarian, 6(21): 281-288.

Balbinot Junior AA, Moraes A, Veiga M, Pelissari A, Dieckow J (2009) Integração lavoura-pecuária: intensificação de uso de áreas agrícolas. Ciência Rural, 39(6): 1925-1933. DOI:10.1590/S010384782009005000107.

Bortolini MF, Fortes AMT (2005) Efeitos alelopáticos sobre a germinação de sementes de soja (Glicine max L.Merrill). Semina: Ciências Agrárias, 26(1):5-10. DOI:

0359.2005v26n1p5.

Brandt EA, Souza LCF, Vitorino ACT, Marchetti ME (2006) Desempenho agronômico de soja em função da sucessão de culturas em sistema de plantio direto. Ciência e Agrotecnologia, 30(5): 869-874. DOI: $10.1590 /$ S1413-70542006000500007

Brasil. Ministério da Agricultura, Pecuária e Abastecimento (2009). Regras para análise de sementes. Ministério da Agricultura, Pecuária e Abastecimento. Secretaria de Defesa Agropecuária. - Brasília: Mapa/ACS. 399 p.

Carvalho PCC, Anghinoni I, Moraes A, Souza ED, Sulc RM, Lang CR, Flores JPC, Lopes MLT, Silva JLS, Conte O, Wesp CL, Lieven R, Fontaneli RS, Bayer C (2010) Managing grazing animals to achieve nutriente cycling and soil improvement in no-till integrated systems. Nutrient Cycling in Agroecosystems, 88: 259-273. DOI:10.1007/s10705010-9360-X.

CONAB - Companhia Nacional de Abastecimento (2015). Acompanhamento da safra brasileira de grãos. V.3 - Safra 2015/2016. N.1 - Primeiro levantamento intenção de plantio Outubro/2015. p. 1-141. Disponível em: http://www.conab.gov.br/OlalaCMS/uploads/arqui vos/15_10_09_09_03_07_boletim_graos_outubro_201 5.pdf. Ácesso em $\overline{1} 2$ dez 2015. 
Cruz JC, Pereira Filho IA, Alvarenga RC, Gontijo Neto, MM, Viana JHM, Oliveira MF, Matrangolo WJR (2010) Cultivo do milho. Embrapa Milho e Sorgo: Sistema de Produção, 1, 6. ed. Disponível em: http://www.cnpms.embrapa.br/publicacoes/milho_6_ed /index.htm. (Acesso em 03 dez.2014).

Flores JPC, Anghinoni I, Cassol LC, Carvalho PCF, Leite JGDB, Fraga TI (2007) Atributos físicos do solo e rendimento de soja em sistema de plantio direto em integração lavoura-pecuária com diferentes pressões de pastejo. Revista Brasileira de Ciência do Solo, 31(4): 771-780 (Seção VI - Manejo e conservação do solo e da água). DOI:10.1590/S010006832007000400017

Flores JP, Tracy B (2012) Impacts of winter feeding on pasture soils and plants. Agriculture, Ecosystems and Environment, 149:

DOI: 10.1016/j.agee.2011.12.009

Kubo CT, Mata JDV, Silva MAG, Sengik E, Muniz AS, Neiro ES (2007) Produtividade de soja em plantio direto em sucessão ao trigo, aveia branca, aveia preta com e sem adubação nitrogenada. Acta Scientarum $\begin{array}{lll}\text { Agronomy, } & \text { 29(2): } 235-240 . & \text { DOI: }\end{array}$ 10.4025/actasciagron.v29i2.257

Kunrath TR, Carvalho PCF, Cadenazzi M, Bredemeier C, Anghinoni I (2015) Grazing management in na integrated crop-livestock system: soybean development and grain yeld. Ciência Agronômica, 46(3): 645-653. DOI: 10.5935/1806-6690.20150049

Lira RK, Fortes AMT, Camozzato AM (2010) Alelopatia de espécies forrageiras na germinação e no crescimento da soja. Cultivando o Saber, 3(4): 67-75.

Lopes MLT, Carvalho PCF, Anghinoni I, Santos DT, Aguinaga AA, Flores JPC, Moraes A (2009) Sistema de integração lavoura-pecuária: efeito do manejo da altura em pastagem de aveia preta e azevém anual sobre o rendimento da cultura da soja. Ciência Rural, 39(5): 1499-1506.

Lunardi R, Carvalho PCF, Trein CR, Costa JÁ, Cauduro GF, Barbosa CMP, Aguinaga AAQ (2008) Rendimento de soja em sistema de integração lavoura-pecuária: efeito de métodos e intensidades de pastejo. Ciência Rural, 38(3): 795-801.

Moraes A, Carvalho PCF, Anguinoni I, Lustosa SBC, Costa SEVGA, Kunrath TR (2013) Integrated croplivestock systems in the Brazilian subtropics. European Journal of Agronomy, $x x(x x)$ : 1-6. DOl: 10.1016/.eja.2013.10.004.

Moraes A, Carvalho PCF, Lustosa SBC, Lang CR, Deiss L (2014) Research on integrated crop-livestock systems in Brazil. Revista Ciência Agronômica, 45(5): 1024-1031. Doi: 10.1590/S1806-66902014000500018.

Mut Z, Sezer I, Gülümser A (2005) Effect of different sowing rates and nitrogen levels on grain yeld, yeld components and some quality traits of triticale. Asian Journal of Plant Sciences, 4(5): 533-539. DOI: 10.3923/ajps.2005.533.539
Piano JT, Oliveira PSR, Costa PF, Taffarel LE, Egewarth JF, Seidel EP, Castagnara DD, Borsoi A, Egewarth VA (2015) Soil physical attibutes under diferente grazing management of winter forage crops in crop-livestock system at Soutthern Brazil. African Journal of Agricultural Research, 10(3): 146-153. DOl: 10.5897/AJAR2014.8943.

Salton JC, Mercante FM, Tomazi M, Zanatta JA, Concenço G, Silva WM, Retore M (2014) Integrated crop-livestock system in tropical Brazil: Toward a sustainable production system. Agriculure, Ecosystems and Environment, 190: 70-79 DOI:10.1016/j.agee.2013.09.023

Santos HP, Fontaneli RS, Spera ST, Maldaner GL (2013) Rendimentos de grãos de soja em diferentes sistemas de produção integração lavoura-pecuária. Revista Brasileira de Ciências Agrárias, 8(1): 49-56. DOI:10.5039/agraria.v8i1a2077

Santos HP, Fontaneli RS, Pires JLF, Fontaneli RS, Biazus V, Verdi AC, Vargas AM (2014) Rendimento de grãos e característica agronômica da soja em função de pastagens perenes em sistema de plantio direto. Bragantia, 73(3): 319-326. DOI: 10.1590/16784499.0153

SEAB - Secretara de Estado da Agricultura e do Abastecimento (2014) Departamento de Economia Rural (Deral). Soja - análise da conjuntura agropecuária. p.1-17. Disponível em: http://www.agricultura.pr.gov.br/arquivos/File/deral/Pro gnosticos/soja_2013_14.pdf. (Acesso em 14 set. 2014)

Sfredo G J (2008) Calagem e adubação da soja. Londrina: Embrapa Soja, p.12. (Circular Técnica, 61).

Silva HA, Moraes A, Carvalho PCF, Fonseca AF, Dias CTS (2012) Maize and soybeans production in integrated system under no-tillage with different pasture combinations and animal categories. Revista Ciência Agronômica, 43(4): 757-765. DOl: 10.1590/S1806-66902012000400018

Silva FD, Amado TJC, Ferreira AO, Assmann JM, Inghinoni I, Carvalho PCF (2014) Soil carbono índices as affected by 10 years of integrated crop-livestock production with diferente pasture grazing intensities in Southern Brazil. Agriculture, Ecosystems and Environment, 190: 60-69. DOl: 10.1016/j.agee.2013.12.005

Vazquez GH, Carvalho NM, Borba MMZ (2008) Redução na população de plantas sobre a produtividade e a qualidade fisiológica da semente de soja. Revista Brasileira de Sementes, 30(2): 01-11. DOI: 10.1590/S0101-31222008000200001

Zamarchi G, Pavinato PS, Menezes LFG, Martin TN (2014) Silagem de aveia branca em função da adubação nitrogenada e pré-murchamento. Semina: Ciências Agrárias, 35(4): 2185-2196. DOI: 10.5433/1679-0359.2014v35n4p2185. 